\title{
A Study of the Catalytic Properties of Synthetic Aluminosilicates of Different Morphologies in Cracking Reactions of the Byproducts of Isoprene Synthesis
}

\author{
Yu. A. Alikina ${ }^{a, *}$, E. A. Spetsov ${ }^{b}$, N. Yu. Ulyanova ${ }^{a}$, and O. Yu. Golubeva ${ }^{a}$ \\ ${ }^{a}$ Grebenshchikov Institute of Silicate Chemistry, Russian Academy of Sciences, St. Petersburg, 199034 Russia \\ ${ }^{b}$ Saint Petersburg State Technological Institute (Technical University), St. Petersburg, 190013 Russia \\ *e-mail:morozowa_u_a@mail.ru \\ Received February 12, 2021; revised April 30, 2021; accepted June 7, 2021
}

\begin{abstract}
The catalytic activity of synthetic samples of aluminosilicates of various morphologies and chemical compositions in a cascade of reactions that are byproducts (BPs) in the decomposition process of 4,4-dimethyl-1,3-dioxane is studied. Aluminosilicates with montmorillonite structures $\left(\mathrm{Na}_{0.2} \mathrm{Al}_{1.8} \mathrm{Mg}_{0.2} \mathrm{Si}_{4} \mathrm{O}_{10}(\mathrm{OH})_{2} \cdot n \mathrm{H}_{2} \mathrm{O}, \mathrm{Mg}_{3} \mathrm{Si}_{4} \mathrm{O}_{10}(\mathrm{OH})_{2} \cdot n \mathrm{H}_{2} \mathrm{O}\right)$, and kaolinite $\left(\mathrm{Al}_{2} \mathrm{Si}_{2} \mathrm{O}_{5}(\mathrm{OH})_{4}\right)$ with the spherical and platy morphologies of particles, as well as their porous-textural characteristics and surface properties, are studied. It is shown that the specific surface area of the studied samples, depending on the composition, varies from 11 to $470 \mathrm{~m}^{2} / \mathrm{g}$, and the content of aluminum oxide in the samples ranged from 0 to $24 \mathrm{wt} \%$. It is found that layered silicates with a montmorillonite structure contribute to reducing the gasification of organic raw materials and increasing the yield of isoprene. Kaolinite with a spherical morphology of particles increases the yield of formaldehyde, and with a platy morphology of particles, it increases the degree of decomposition of heteroatomic and cyclic compounds.
\end{abstract}

Keywords: catalysis, cracking, montmorillonite, kaolinite, saponite, bentonite

DOI: $10.1134 / \mathrm{S} 1087659621050035$

\section{INTRODUCTION}

The petrochemical processes related to the production of isoprene for the production of synthetic rubbers (SRs), as a rule, are accompanied by the formation of a wide range of byproducts (BPs) (for example, dioxane alcohols, hydropyrans, and esters [1-3]). The latter are mainly used as fuel in waste heat boilers and are only partially processed technologically with the useful products being recycled [4]. BPs are processed by steam cracking on catalysts in the form of aluminosilicates, the action of which is aimed at the decomposition of isobutylene and formaldehyde derivatives and their oligomers in a steam atmosphere. The selectivity of such catalysts during their modernization is aimed at increasing the depth of decomposition of the components of the mixture and minimizing the degree of their gasification and compaction (polymerization, coke formation) by the BPs $[5,6]$.

Scheme 1 [7] illustrates the routes of the formation of the main and secondary components in the process of synthesizing isoprene. It should be noted that 3-methylbutanediol-1,3 is not an initiating agent; its transformations have the longest chain of reactions.
Other components of organic raw materials enter into these and other reactions, forming a wide range of substances. This diagram is incomplete. In the chain of transformations, 4-methyl-3,6-dihydropyran is formed as the final product during the main process of the production of synthetic rubber monomers; and its content is highest in the organic mixture and is comparable only with the concentration of dioxane alcohols. However, during thermocatalytic decomposition, they are important sources for the production of the main commercial products: formaldehyde and 2-methyl-1,3-butadiene. Another product, 3-methylbuten-3-ol, is the main raw material for the production of citral and vitamins A and E [8]. Simultaneously, the action of the catalyst leads to the formation of undesirable heavy and light products by terpene oligomers and gaseous $\mathrm{CO}, \mathrm{CO}_{2}$, and hydrocarbons. While heavy products are the result of polymerization reactions between, presumably, heteroatomic compounds, light products are formed as a result of the decomposition of formaldehyde and cracking of alcohols [9]. 
<smiles>CC1=CCOCC1</smiles><smiles>CCCO</smiles><smiles>CC1(O)CCOCC1</smiles><smiles>OCO</smiles>

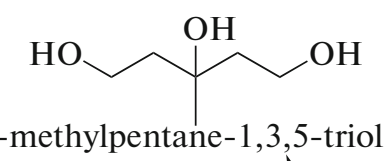

4-methyltetrahydro-dihydropyranol-4

4-methyl-3,6-dihydropyran

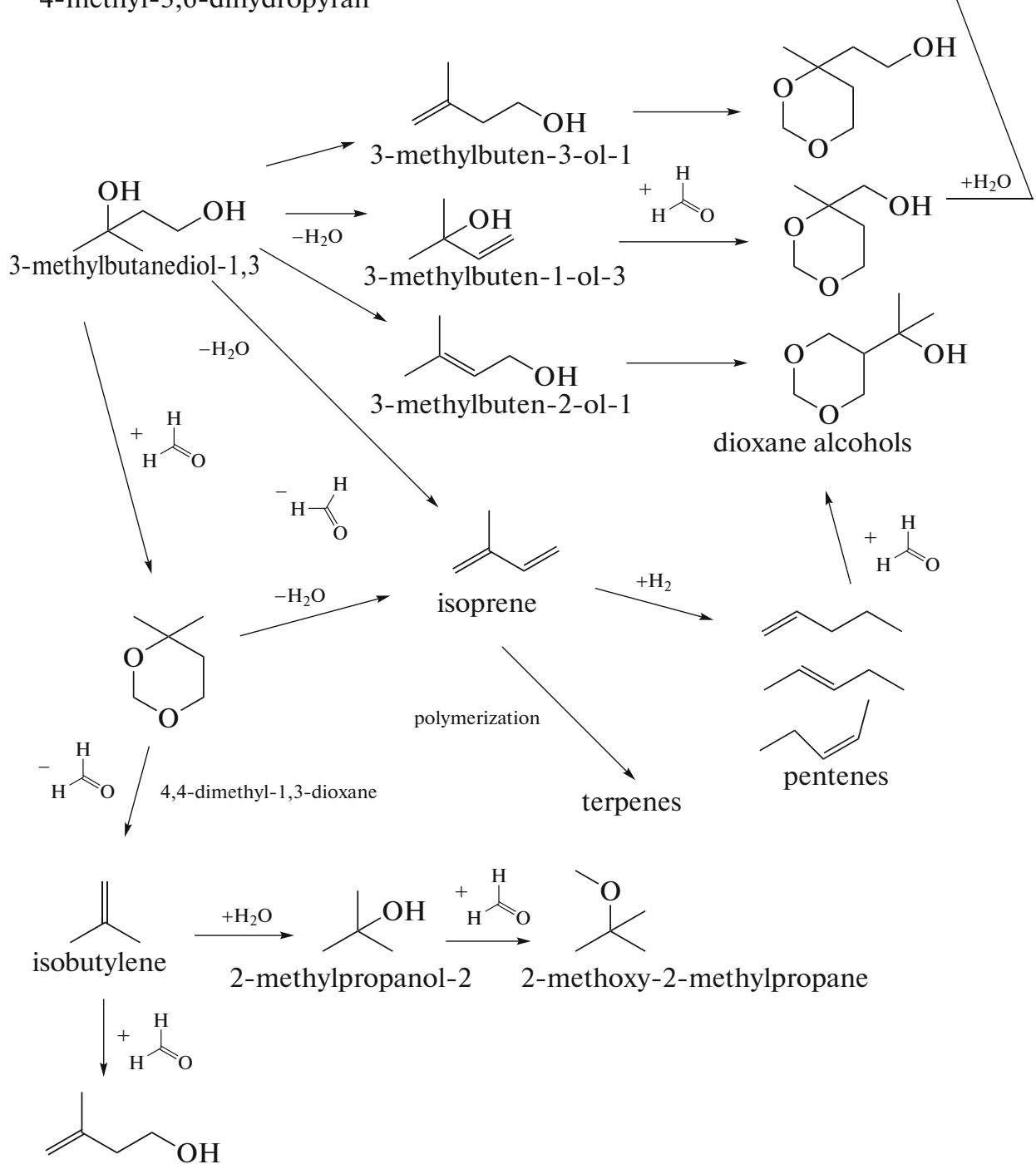

3-methylbuten-3-ol-1

Scheme 1. Formation of targeted products and BPs in isoprene synthesis reactions [7].

The existing technology makes it possible to process not more than two-thirds of the BPs into useful products $[10,11]$. Theoretically, nontargeted products of synthetic rubber production can be catalytically transformed into targeted products: isobutylene, isoprene, and formaldehyde. However, in practice, i.e., with the simultaneous processing of a mixture of these substances, the unification of the conditions for their conversion and, as a consequence, an increase in the number of secondary side reactions denies the possibility of achieving the maximum selectivity for the dis- sociation of each of the components. The use of natural aluminosilicates containing impurities of various oxides causes catalysis on the surface with phase polymorphism [12, 13]. In other words, many of the available catalyst surface structures ensure that it is multiroute, but not selective.

Over the past few years of development, the composition of existing catalysts based on natural clays was entirely determined by the composition of the resulting $\mathrm{BP}$ of the decomposition products (for example, [14-20]). General regularities were derived, according 
Table 1. Synthesis conditions, morphology and designations of the test samples

\begin{tabular}{l|l|c|l}
\hline Sample designation & Composition of the original gel & $\begin{array}{c}\text { Temperature } \\
\text { hydrothermal treatment }\end{array}$ & \multicolumn{1}{|c}{$\begin{array}{c}\text { Expected morphology } \\
\text { particles }\end{array}$} \\
\hline Kaol-250 & $\mathrm{Al}_{2} \mathrm{Si}_{2} \mathrm{O}_{5}(\mathrm{OH})_{4}$ & $250^{\circ} \mathrm{C}$ & Spherical \\
Kaol-350 & $\mathrm{Al}_{2} \mathrm{Si}_{2} \mathrm{O}_{5}(\mathrm{OH})_{4}$ & $350^{\circ} \mathrm{C}$ & Platy \\
Sap & $\mathrm{Mg}_{3} \mathrm{Si}_{4} \mathrm{O}_{10}(\mathrm{OH})_{2} \cdot n \mathrm{H}_{2} \mathrm{O}$ & $350^{\circ} \mathrm{C}$ & Layered \\
Mt & $\mathrm{Na}_{0.2} \mathrm{Al}_{1.8} \mathrm{Mg}_{0.2} \mathrm{Si}_{4} \mathrm{O}_{10}(\mathrm{OH})_{2} \cdot n \mathrm{H}_{2} \mathrm{O}$ & $350^{\circ} \mathrm{C}$ & Layered \\
\hline
\end{tabular}

to which the more severe decomposition of BPs corresponded to a higher content of phases, including aluminum and other transition metals in the catalyst. These phases increased the degree of gasification and compaction of the feedstock. Clays rich in such elements had similar catalytic properties, for example, bentonite and Cambrian. The opposite effect was observed for clays with impurities of alkali metal oxides, for example, kaolinic [21]. By reducing the proportion of the volatile compounds and coke formed, they simultaneously inhibited the formation of the useful products; i.e., they reduced the conversion and selectivity of the entire process. The addition of alkaline earth metals to clays, as a rule, did not greatly affect their conversion, but could shift the selectivity of the ongoing processes in favor of incidental components. In relation to this, the main mineral components for the production of catalysts are bentonite and kaolin clays, feldspar, and quartz [12]. However, there is no information on the catalytic role of the phases that make up these components in the process under consideration.

In relation to this, the analysis of some individual aluminosilicate structures is of interest in order to determine the degree of conversion and the selectivity of their action to the individual components of the BP mixture under consideration. This would make it possible to outline an approach to replace natural aluminosilicates with combined polyfunctional catalysts for processing multicomponent heavy distillates from synthetic rubber production and other industries.

This paper presents the results of a study of the microstructural and textural characteristics, as well as the catalytic properties, of aluminosilicates of the kaolinite group: $\mathrm{Al}_{2} \mathrm{Si}_{2} \mathrm{O}_{5}(\mathrm{OH})_{4}$ with a spherical and platy particle morphology, saponite $\mathrm{Mg}_{3} \mathrm{Si}_{4} \mathrm{O}_{10}(\mathrm{OH})_{2} \cdot n \mathrm{H}_{2} \mathrm{O}$ and montmorillonite $\mathrm{Na}_{0.2} \mathrm{Al}_{1.8} \mathrm{Mg}_{0.2} \mathrm{Si}_{4} \mathrm{O}_{10}(\mathrm{OH})_{2} \cdot n \mathrm{H}_{2} \mathrm{O}$ versus polymorphic kaolin and bentonite clay catalysts. The studied samples of aluminosilicates were obtained under the conditions of directed hydrothermal synthesis, which made it possible to study samples of the given phase and chemical composition, as well as morphology; and with a certain set of microstructural and porous-textural characteristics, to study the effect of these characteristics on the catalytic activity of samples in cracking reactions of BPs of the synthesis of isoprene, which is not possible in the case of studying natural aluminosilicates.

\section{EXPERIMENTAL}

Synthesis of aluminosilicate catalysts. The synthesis was carried out by the hydrothermal treatment of dried gels of the corresponding compositions in steel autoclaves with platinum crucibles. The composition of the gels was calculated based on the ideal formula of the final products: kaolinite, saponite, and montmorillonite (Table 1).

The initial gels were prepared using tetraethoxysilane (TEOS) $\left(\left(\mathrm{C}_{2} \mathrm{H}_{5} \mathrm{O}\right)_{4} \mathrm{Si}\right.$, special purity grade), $\mathrm{Mg}$ $\left(\mathrm{NO}_{3}\right)_{2} \cdot 6 \mathrm{H}_{2} \mathrm{O}$ (chemically pure), $\mathrm{Al}\left(\mathrm{NO}_{3}\right)_{3} \cdot 9 \mathrm{H}_{2} \mathrm{O}$ (chemically pure), $\mathrm{HNO}_{3}$ (chemically pure, $65 \mathrm{wt} \%$ ), $\mathrm{NH}_{4} \mathrm{OH}$ (special purity grade), and ethyl alcohol, using the previously described methods [22, 23].

The dried gels were subjected to hydrothermal treatment at temperatures of 250 and $350^{\circ} \mathrm{C}$ and autogenous pressure of 500 to $700 \mathrm{MPa}$ for three days. The crystallization products were washed with distilled water and dried at $100^{\circ} \mathrm{C}$ for $12 \mathrm{~h}$.

\section{RESEARCH METHODS}

The synthesized samples of aluminosilicate catalysts were studied by X-ray diffraction analysis on a D8-Advance powder diffractometer (Bruker, $\mathrm{Cu} K_{\alpha}$-radiation). The phase analysis of the samples was investigated by comparing the obtained diffraction patterns with those given in the ICCD-2006 database.

The thermal stability of the samples was investigated on a device for synchronous thermal analysis using the method of differential scanning calorimetry (NETZSCH, STA 429), coupled to a QMS 403 C quadrupole mass spectrometer. The studies were carried out at a heating rate of $20^{\circ} \mathrm{C} / \mathrm{min}$, in air, in the temperature range from 20 to $100^{\circ} \mathrm{C}$.

The porous structure of the samples was studied by low-temperature nitrogen sorption (Quantachrome NOVA 1200e, United States). Degassing was carried out at a temperature of $300^{\circ} \mathrm{C}$ for $12 \mathrm{~h}$. The specific surface area of the samples was calculated using the Brunauer-Emmett-Teller (BET) method using the NOVAWin software.

Chemical analysis of the samples for the content of $\mathrm{Si}, \mathrm{Mg}$, and $\mathrm{Al}$ was carried out by the gravimetric method using quinolate of a silicon-molybdenum complex and by complexometric titration. The sodium content in the samples was determined by flame pho- 
tometry on an iCE3000 atomic absorption spectrometer. The $\mathrm{H}_{2} \mathrm{O}$ content was estimated by the weight loss upon calcining the sample at $1000-1100^{\circ} \mathrm{C}$.

Micrographs of the samples were obtained on a Carl Zeiss Merlin scanning electron microscope with a field emission cathode and a GEMINI-II column of electronic optics. The powders were planted directly onto a conductive carbon tape without additional treatment.

The functional composition of the surface of the samples was investigated by the method of adsorption of acid-base indicators with different $p K a$ values in the range from -4.4 to 14.2 , which are selectively sorbed on the surface of active sites with the corresponding pKa values [24]. The content of the adsorption centers was determined from the change in the optical density of aqueous solutions of indicators using the method of UV absorption spectroscopy (LEKISS2109UV spectrophotometer).

Catalytic activity studies. The catalytic activity of the synthesized aluminosilicates was studied using the setup whose schematic diagram is shown in Scheme 2. As a model process for the study, a cascade of reactions was chosen that are side reactions in the process of decomposition of 4,4-dimethyl-1,3-dioxane. Steam cracking of a mixture of oxygen-containing compounds was carried out in a flow reactor at a temperature of $480^{\circ} \mathrm{C}$, volumetric flow rate of the mixture $0.7 \mathrm{~h}^{-1}$, and the ratio of raw materials : water $=1: 3$; the process lasted 2 hours.

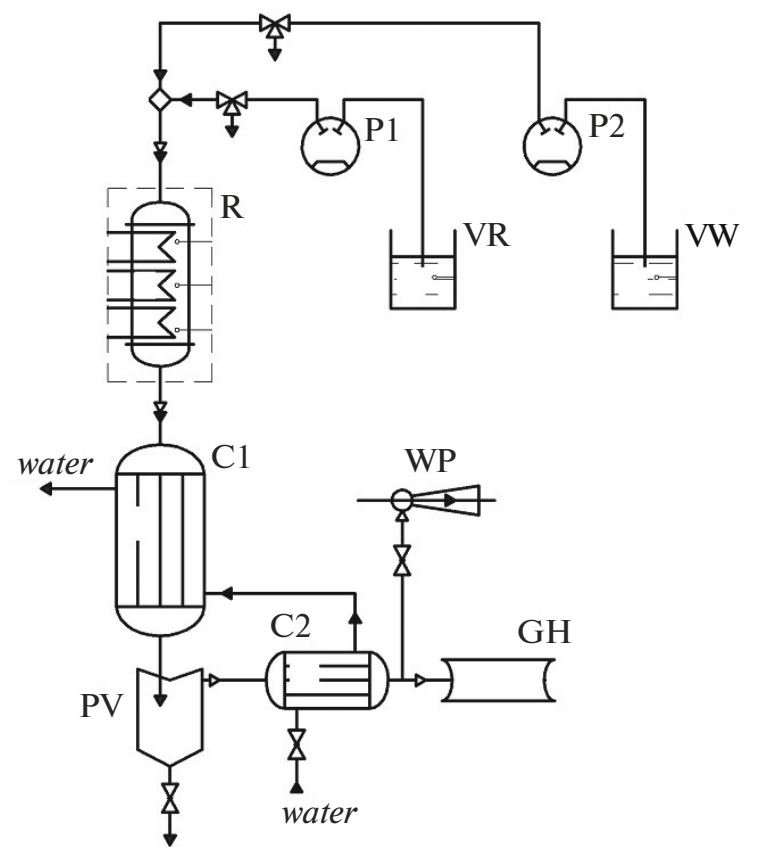

Scheme 2. Schematic diagram of the setup for studying the catalytic activity of samples: R, reactor; P1, feed pump; P2, water pump; VR, raw material capacity; VW, water tank; C1 and $\mathrm{C} 2$, refrigerators for primary and secondary vapor condensation; PV, separating funnel; GH, gas holder; WP, vacuum water pump.
For all samples, the degree of conversion (formation or decomposition) was assessed for the individual components of the organic mixture and the product by processing quantitative data on the content of the components before and after the reaction. The initial organic and final mixtures were analyzed using gas chromatographs. For liquid samples, a Chromatek 5000.2 (Russia) with a flame ionization detector was used. Column filler CP Wax (length $25 \mathrm{~m}$, diameter $0.32 \mathrm{~mm}$ ), thermostat heating rate from 50 to $250-$ $8^{\circ} \mathrm{C} / \mathrm{min}$, carrier gas velocity (hydrogen) $1 \mathrm{dm}^{3} / \mathrm{min}$, and temperature of the detector, $250^{\circ} \mathrm{C}$, and of the evaporator, $220^{\circ} \mathrm{C}$. For gaseous samples, a Kristall 2000M (Russia) with a thermal conductivity detector was used. The column packing consists of molecular sieves (length $40 \mathrm{~m}$ ); carrier gas velocity (hydrogen) $30 \mathrm{~cm}^{3} / \mathrm{min}$; and temperature: detector $100^{\circ} \mathrm{C}$ and evaporator $60^{\circ} \mathrm{C}$.

Raw materials and water were pumped through a mixer into the reactor. The reaction products of the steam conversion were cooled in refrigerators and sent to the product collector. The gaseous products were additionally cooled, and steam condensate also entered the product collector. Uncondensed gases, passing through the sampling vessel (or gas holder), were discharged into the exhaust ventilation. During the annealing of coke products on the catalyst, air was passed through the system using a water vacuum pump. The mass of the coke removed was determined gravimetrically from the change in the mass of the alkaline $\mathrm{CO}_{2}$ adsorbent.

Before testing, the synthesized samples were molded by mixing the aluminosilicate powders with colloidal silicon dioxide and water, and then extrusion was used to obtain cylindrical granules (diameter $1 \mathrm{~mm}$, length $2-3 \mathrm{~mm}$ ) with sufficient mechanical strength for testing in a flow reactor. The catalysts for comparison from natural bentonite and kaolin clays were prepared in the same way. Taking into account the operating temperature of the catalyst, before testing, all samples were calcined at a heating rate of not more than $5^{\circ} \mathrm{C} / \mathrm{min}$ to the final temperature of $500^{\circ} \mathrm{C}$ in atmospheric air.

\section{RESULTS AND DISCUSSION}

The results of the X-ray phase analysis showed that the synthesized samples were single-phase aluminosilicates of the given structural types: kaolinite, saponite, and montmorillonite. (Fig. 1).

Saponite $\left(\mathrm{Mg}_{3} \mathrm{Si}_{4} \mathrm{O}_{10}(\mathrm{OH})_{2} \cdot n \mathrm{H}_{2} \mathrm{O}\right)$ can be considered as a special case of montmorillonite $\mathrm{Na}_{2 x}\left(\mathrm{Al}_{2(1-x)}\right.$, $\left.\mathrm{Mg}_{2 x}\right) \mathrm{Si}_{4} \mathrm{O}_{10}(\mathrm{OH})_{2} \cdot n \mathrm{H}_{2} \mathrm{O}$ with $x=1$. It is distinguished from montmorillonite by the absence of isomorphic substitutions in the octahedral layers, which leads to the almost complete absence of surface charge and exchangeable cations, in particular, of sodium cations, 
(a)

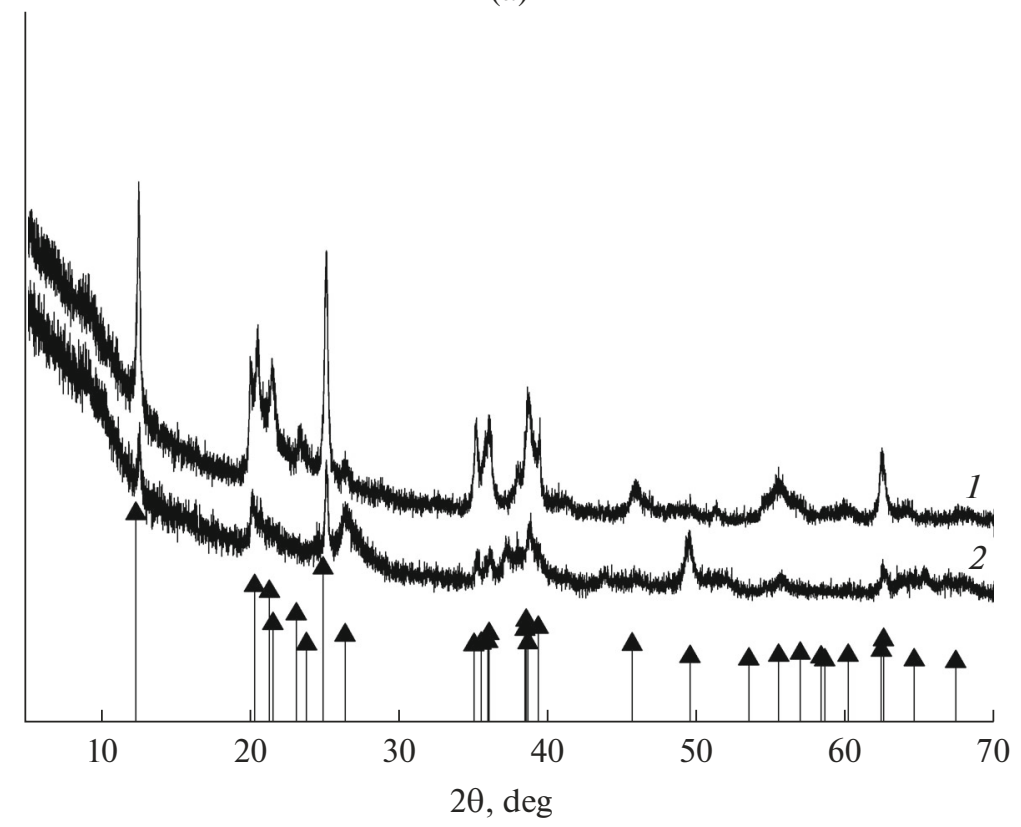

(b)

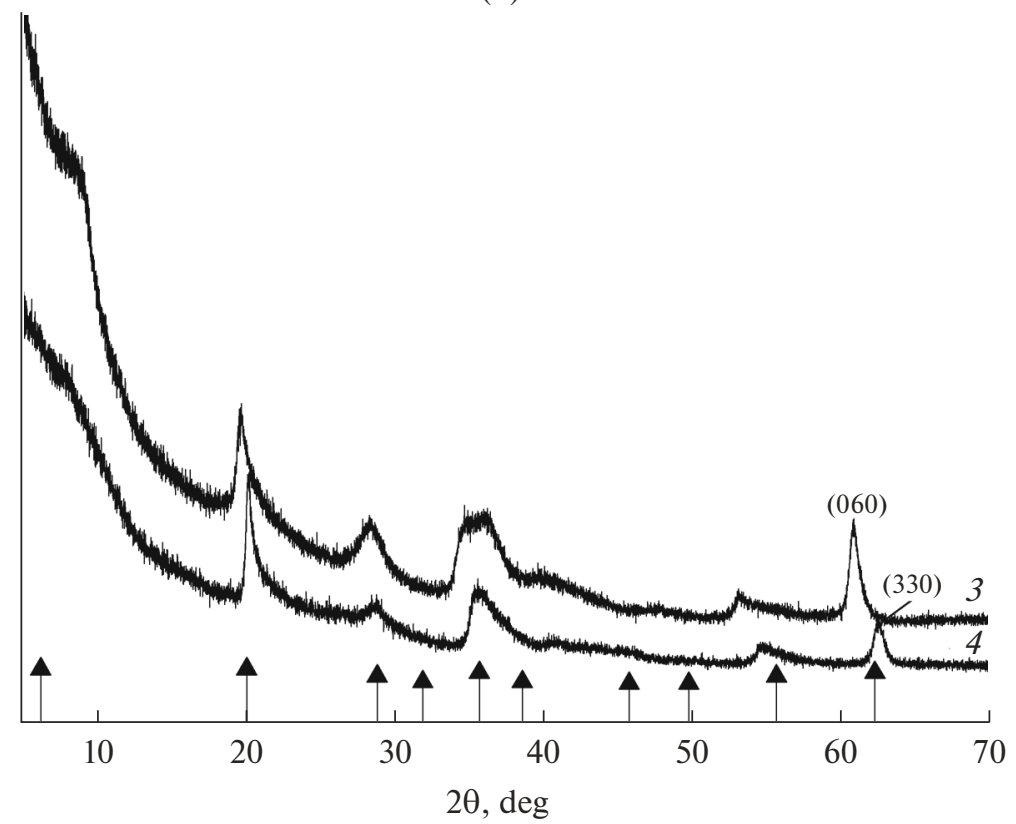

Fig. 1. Diffraction patterns of the synthesized aluminosilicates: Kaol-350 (1), Kaol-250 (2) (a); Sap (3), Mt (4) (b). ^, bar chart standards.

which is confirmed by the results of the chemical analysis (Table 2).

The presence of the $(060)$ reflection on the diffractogram of the Sap sample (Fig. 1) indicates the trioctahedral structure of the sample and the presence of vacancies in the octahedral layers. The Mt sample is characterized by the presence of aluminum in the octahedral layers, which leads to a decrease in the number of vacancies and a transition to the trioctahe- dral structure of the samples $\left(2 \theta=60.8^{\circ}, d=1.48 \AA\right.$, (060)) to dioctahedral $\left(2 \theta=62.3^{\circ}, d=1.52 \AA,(330)\right)^{1}$.

The studied samples contain approximately the same amount of $\mathrm{Al}_{2} \mathrm{O}_{3}$ is $23-24 \mathrm{wt} \%$, except for the Sap sample, which does not contain aluminum (Table 2).

\footnotetext{
${ }^{1}$ Montmorillonites (smectites) can be dioctahedral if two-thirds of the positions in the octahedral layers are occupied by trivalent cations, and trioctahedral if all positions are occupied by divalent cations.
} 
Table 2. Chemical composition of the studied samples according to the data of chemical analysis

\begin{tabular}{l|c|c|c|c|c}
\hline \multirow{2}{*}{ Sample } & \multicolumn{5}{|c}{ Chemical composition, wt \% } \\
\cline { 2 - 6 } & $\mathrm{SiO}_{2}$ & $\mathrm{Al}_{2} \mathrm{O}_{3}$ & $\mathrm{MgO}$ & $\mathrm{Na}_{2} \mathrm{O}$ & Other BPs \\
\hline Kaol-250 & 66.56 & 23.31 & - & - & 0.96 \\
Kaol-350 & 66.56 & 23.31 & - & - & 0.96 \\
Sap & 54.11 & - & 32.52 & 0.11 & 13.26 \\
Mt & 56.96 & 24.81 & 2.10 & 2.99 & 15.24 \\
\hline
\end{tabular}

Two samples, Sap and Mt, contain sodium, while the sodium oxide content in the Sap sample can be considered insignificant (about $0.1 \mathrm{wt} \%$ ). The Kaol-250 and Kaol-350 samples are pure aluminosilicates without additional impurities.

The samples with a kaolinite structure obtained at different temperatures have the same structural type and chemical composition, but differ in morphology (Fig. 2). For the Kaol-250 sample (Fig. 2a) obtained by hydrothermal crystallization of the gel at $250^{\circ} \mathrm{C}$, spherical morphology with a particle diameter of 100 to $170 \mathrm{~nm}$ is characteristic, the Kaol-350 sample consists of platy particles 120-200 nm thick (Fig. 2b). The Sap and Mt samples have a layered morphology (Figs. 2c, 2d).

The TG and DSC curves of the synchronous thermal analysis show the classic character of the thermal decomposition of clay minerals, in particular, kaolinite (Figs. 3a, 3b) and montmorillonites (Figs. 3c, 3d). All the samples of the studied aluminosilicates lose interlayer and physically sorbed water in the temperature range $100-200^{\circ} \mathrm{C}$. At a temperature of 150 to $400^{\circ} \mathrm{C}$, a weight loss of $6.2 \%$ for Kaol-250 and $0.8 \%$ for Kaol-350 occurs, which is related to the removal of

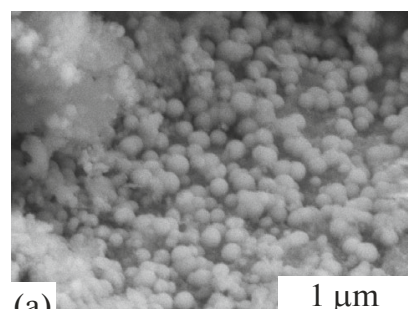

(a)

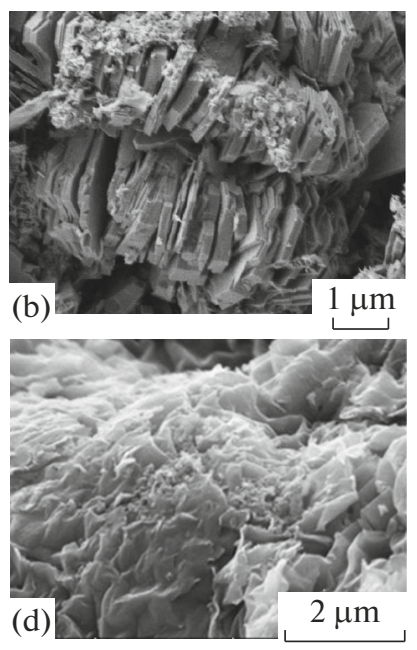

(c)

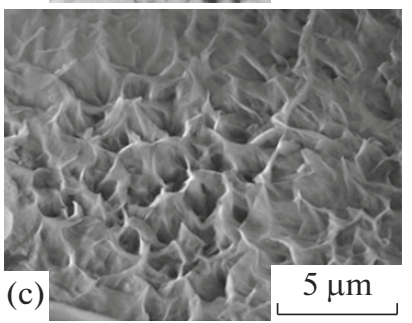

(d) $2 \mu \mathrm{m}$

Fig. 2. Results of studying the synthesized aluminosilicates by electron microscopy: Kaol-250 (a), Kaol-350 (b), Sap (c), Mt (d). the physically bound water. The endothermic peaks at 493 and $535^{\circ} \mathrm{C}$ with 6.57 and $11.45 \%$ weight losses are due to the release of the structurally bound water. An intense exothermic reaction at $1003^{\circ} \mathrm{C}$ without weight loss is observed in both the kaolinite samples. Here, according to various published data, $\gamma-\mathrm{Al}_{2} \mathrm{O}_{3}$ [25], mullite [26], or spinel $\mathrm{Al}_{4} \mathrm{Si}_{3} \mathrm{O}_{12}$ can be formed [27].

The Sap and Mt samples also lose constitutional water, represented by the hydroxyl groups of the layers, and turn into an anhydrous modification. For natural montmorillonites and bentonite clays, the temperature corresponding to this process is in the range of 500 to $700^{\circ} \mathrm{C}$. The outlet temperature of the constitutional water for the synthesized compounds shifts to high temperatures. For the Sap sample, it was $850^{\circ} \mathrm{C}$, with a mass loss of $3.4 \%$. For the Mt sample, this process is a two-stage process and is accompanied by endothermic effects at 700 and $975^{\circ} \mathrm{C}$. The Sap and Mt samples are characterized by the presence of an exothermic peak immediately following the high-temperature endothermic effect related to the destruction of the structure of the samples [28]. In general, the thermal behavior of all the samples under study indicates their thermal stability.

The results of studying the aluminosilicate catalyst samples by the method of low-temperature nitrogen adsorption showed that all the obtained curves (Fig. 4) can be attributed to type IV adsorption isotherms according to the IUPAC classification [29]. They are characterized by the presence of hysteresis, which indicates capillary condensation in the mesopores. The indicated type of isotherms indicates the simultaneous presence of both meso- and micropores $[30,31]$. The adsorption isotherms shown in Fig. 4 differ in the shape of the hysteresis loop, which indicates the different porous-textural characteristics of the samples, in particular, about the different shape of the pores. While for the Kaol-250 and Sap samples the shape of the hysteresis loops can be attributed to the H2 type [32], the Kaol-350 and Mt samples are characterized by a narrowing of the hysteresis loop, while the shape of the loop becomes closer to the $H 3$ type. The hysteresis loops can indicate the shape of the pores and their distribution in the sample. The $H 2$ type is believed to be indicative of mesoporous structures with a pore shape distribution, while the $H 3$ type are usually attributed to aggregates of platy particles that form slit-like pores [29].

The specific surface area values also differ for samples of different morphologies. The size $S_{s p}$ for the Kaol-250 sample with a spherical morphology (Fig. 4a) is $330 \mathrm{~m}^{2} / \mathrm{g}$; and the Kaol-350 sample with platy morphology, only $15 \mathrm{~m}^{2} / \mathrm{g}$. The pore volume is, respectively, 0.521 and $0.089 \mathrm{~cm}^{3} / \mathrm{g}$ for the Kaol-250 and Kaol-350 samples, and the average pore diameter for both samples is $3.8 \mathrm{~nm}$. The specific surface area for the Sap and Mt samples is 219 and $105 \mathrm{~m}^{2} / \mathrm{g}$; the pore diameters, $8.8 \mathrm{~nm}$ and $3.9 \mathrm{~nm}$; and pore volume, 0.6 

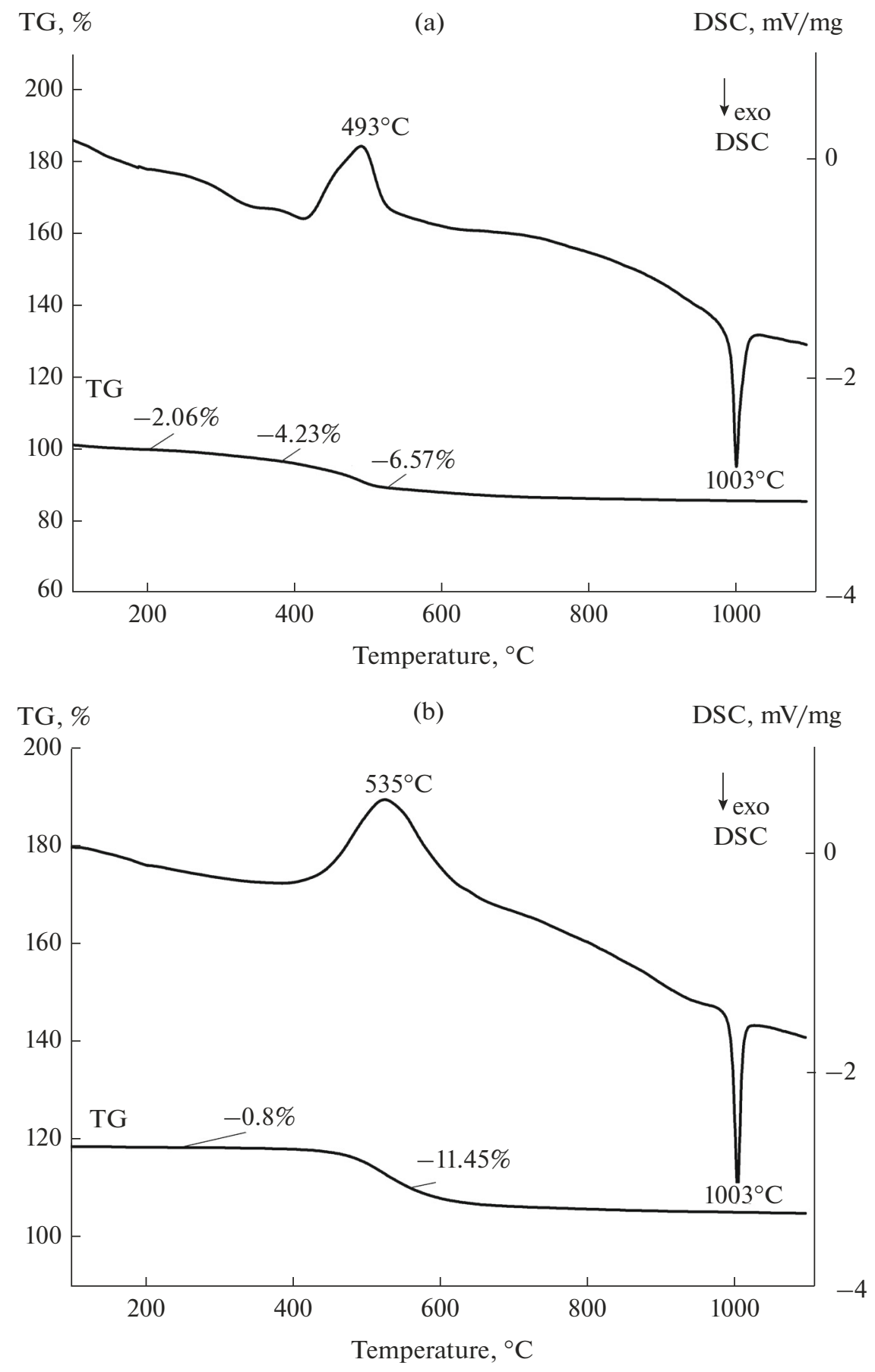

Fig. 3. Differential thermal analysis curves: Kaol-250 (a), Kaol-350 (b), Sap (c), Mt (d).

and $0.46 \mathrm{~cm}^{3} / \mathrm{g}$, respectively. For samples of natural clays, the specific surface area was $16.1 \mathrm{~m}^{2} / \mathrm{g}$ (from bentonite) and $5.7 \mathrm{~m}^{2} / \mathrm{g}$ (from kaolin); and the total pore volume was 0.22 and $0.25 \mathrm{~cm}^{3} / \mathrm{g}$, respectively. The results of the study by the method of low-temperature nitrogen adsorption showed that the obtained samples of aluminosilicate catalysts differ in porosity, shape, and pore size.
An analysis of the surface of the test samples by the method of the adsorption of the acid-base indicators (Fig. 5) allows us to conclude that there are proton (Bronsted) acid sites on the surface of the samples, as well as changes in the strength and ratio between acid sites depending on their chemical composition and morphology.

Samples of all compositions contain weakly acidic Bronsted acid centers (BACs) with pKa 5 and highly 

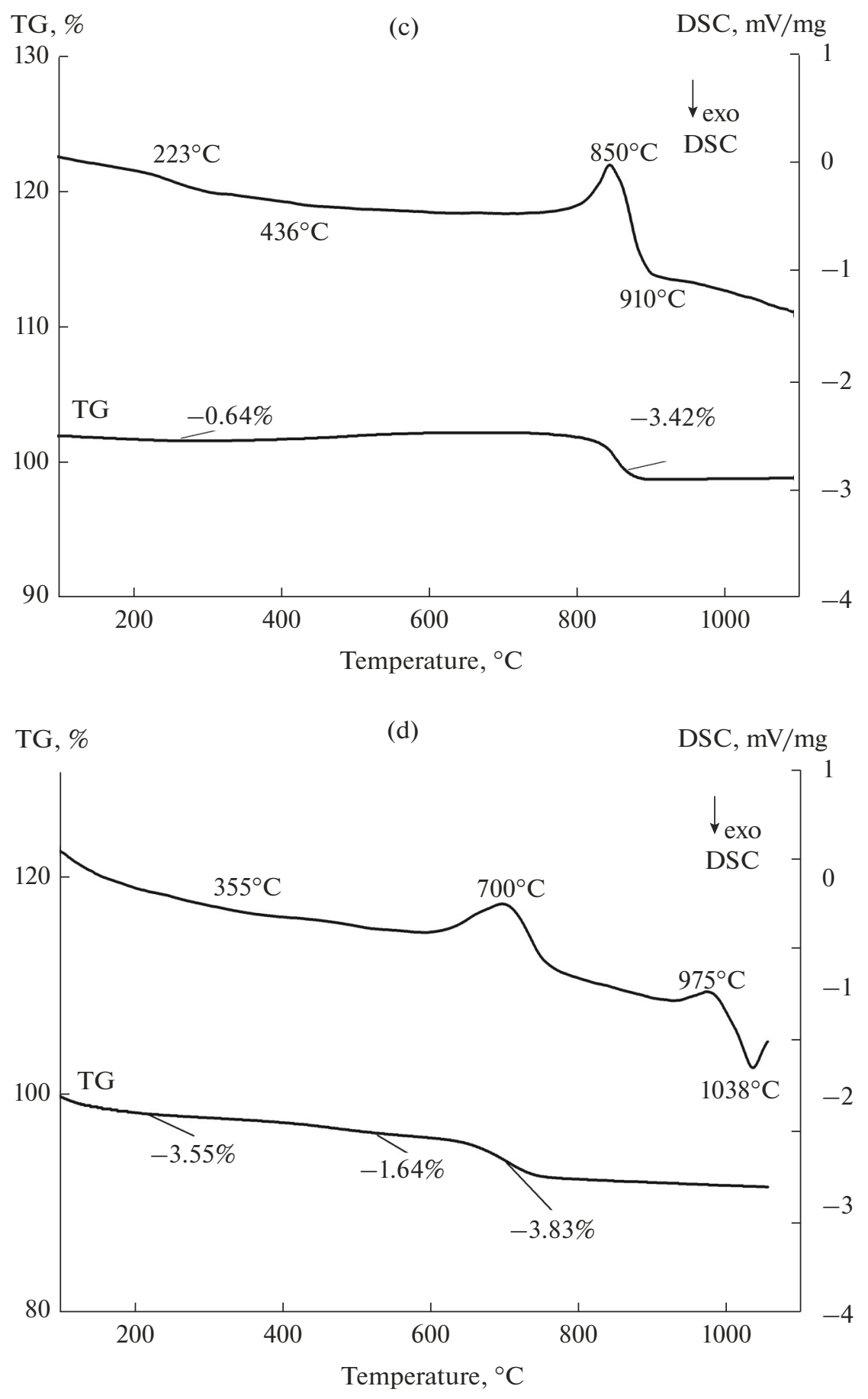

Fig. 3. (Contd.)

acidic BACs with $\mathrm{pKa} 2.5$. All samples are characterized by the presence of a small number of Lewis base centers (LBCs) with pKa-4. Samples of the Kaol-250 and Kaol-350 kaolinite groups are characterized by the presence of BACs located in the pKa range of 2.5 and 5 with values of 40 and $45 \mu \mathrm{mol} / \mathrm{g}$. For the samples of the montmorillonite Sap and Mt group, these values are somewhat lower at 20 and $35 \mu \mathrm{mol} / \mathrm{g}$, respectively. For Kaol-250, the highest Lewis acid center (LAC) concentration, $307 \mu \mathrm{mol} / \mathrm{g}$, is observed in the $\mathrm{pKa}$ region of 14.2. The amount of LAC in the samples of the montmorillonite group is much lower: 72.6 and 201 for Sap and Mt, respectively. The samples of the kaolinite group have the highest surface acidity; the concentration of LACs in them is twice as high as that of the samples of the montmorillonite 
(a)

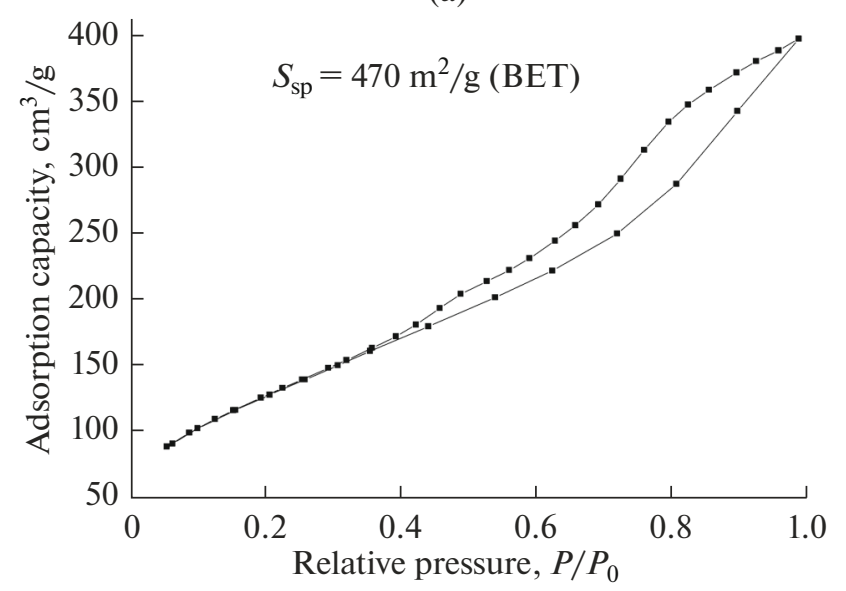

(b)
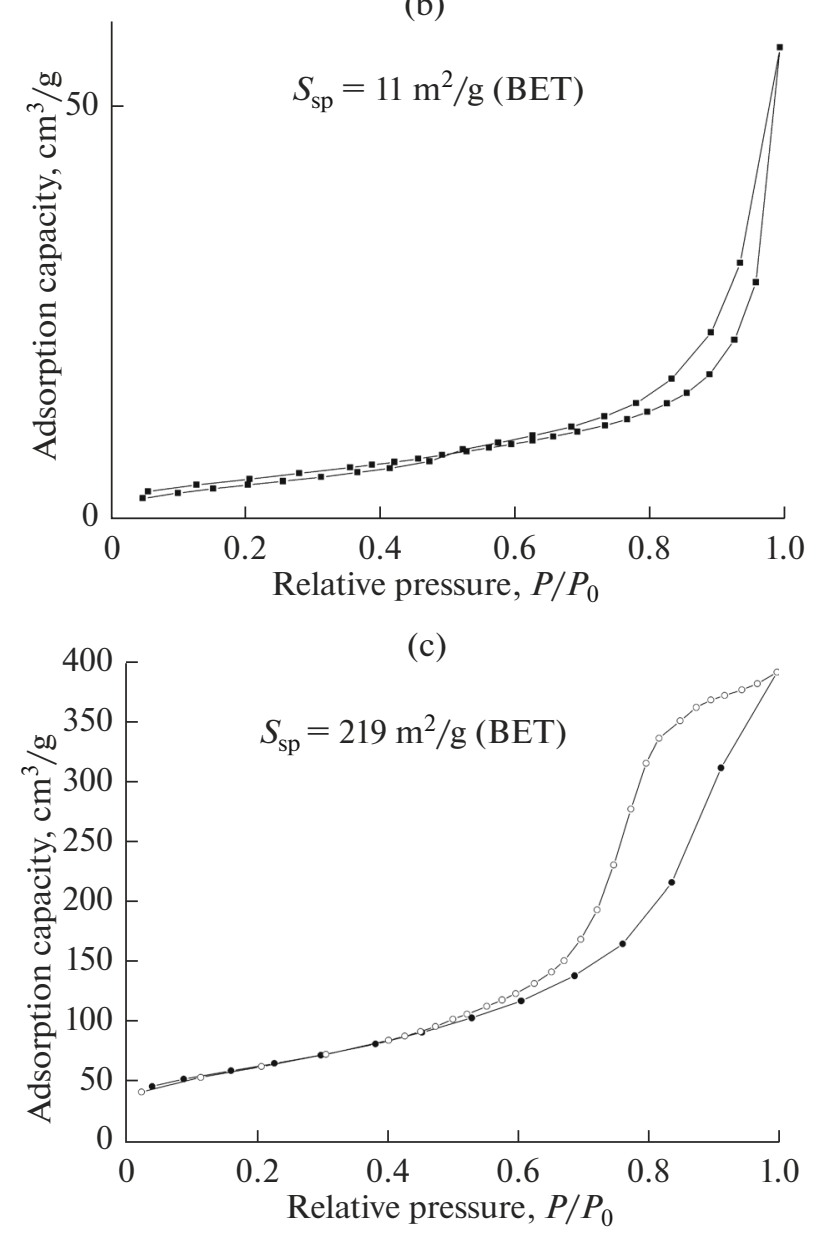

Fig. 4. Nitrogen adsorption isotherms of synthesized aluminosilicates: Kaol-250 (a), Kaol-350 (b), Sap (c), Mt (d).

group. The morphology of the samples (spherical or platy) does not affect the distribution of acid sites on the surface.

It should be noted that the adsorption method of the acid-base indicators does not obtain the values of (d)

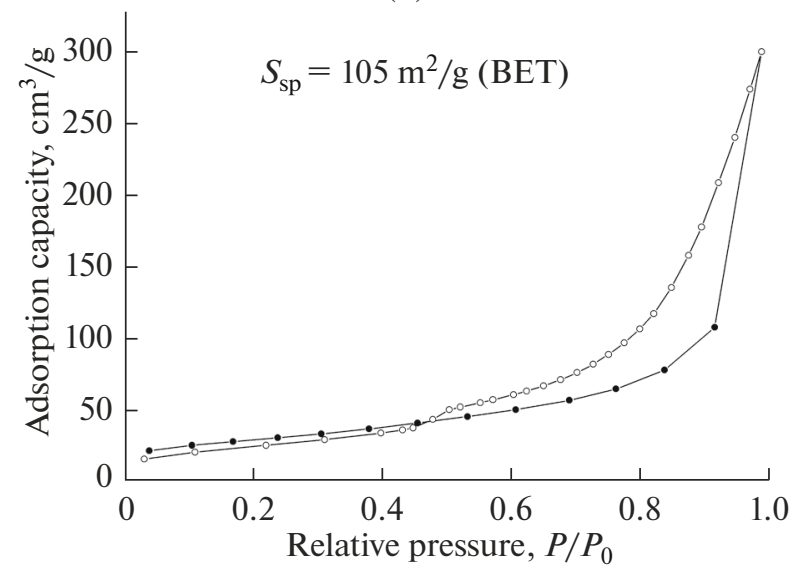

Fig. 4. (Contd.)

true acidity, and for a complete understanding of the mechanism of catalytic activity, studies by the method of ammonia desorption are undoubtedly necessary. The method of adsorption of acid-base indicators is quite simple and makes it possible to predict the properties of the solids used in catalysis at this initial stage of studying the possible influence of the morphology of aluminosilicates and compare the properties of natural samples and their synthetic analogs.

From the results of the study of the catalytic activity of the samples (Table 3), it follows that compounds from $\mathrm{CO}$ to pentenes (except for isobutylene) that are volatile under normal conditions are formed on the catalysts synthesized in an autoclave in total concentrations of up to 3 to $4 \mathrm{wt} \%$. Even this circumstance requires the involvement of additional measures for the purification of gas flows, which can be minimized by reducing the share of gas emissions. A comparison of the activities of the synthesized catalysts does not indicate significant differences between them. Comparative catalysts based on bentonite and kaolin clays, in contrast, are more actively involved in the formation of the gas phase, especially isobutylene, which, however, is the only useful gaseous component here.

A comparison of the degrees of decomposition of the components of an organic mixture of BPs shows that kaolinites are the most promising catalysts. However, such an integral assessment is not entirely objective. From a more detailed comparison of the catalysts in terms of the degree of conversion of the mixture's components, it follows that Mt surpasses kaolinite in the degree of isoprene formation (the main product of the production of SR monomers) and the decomposition of tert-butanol (with the formation of technologically significant isobutylene). Sap consistently loses in terms of activity to other synthetic catalysts.

The decomposition of 3-methylbutanone-2 is a higher energy process that is stable at temperatures above $550^{\circ} \mathrm{C}$. The catalytic action of the studied 


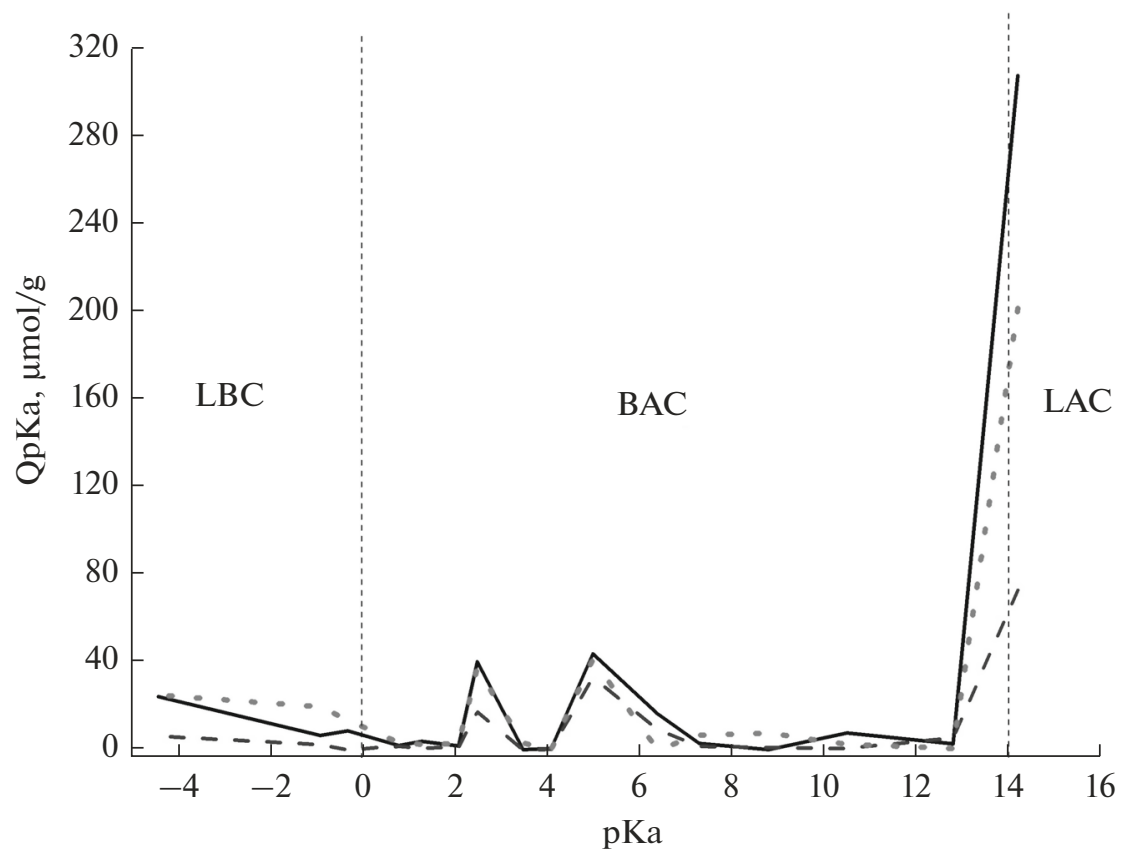

Fig. 5. Distribution of active centers on the surface of synthesized aluminosilicates: continuous, Kaol-250 and Kaol-350; point, Sap; dotted, Mt.

Table 3. Composition of BP steam catalytic cracking products

\begin{tabular}{|c|c|c|c|c|c|c|c|}
\hline \multirow{3}{*}{ Component name } & \multirow{3}{*}{$\begin{array}{c}\text { BP } \\
\text { composition, } \\
\text { wt } \% *\end{array}$} & \multicolumn{6}{|c|}{ Composition of cracking products, wt $\% *$} \\
\hline & & \multicolumn{6}{|c|}{ catalyst sample designation } \\
\hline & & Sap & $\mathrm{Mt}$ & Kaol-250 & Kaol-350 & ** Bent & ** Kaol \\
\hline $\mathrm{CO}$ & - & 0.22 & 0.48 & 1.24 & 0.86 & 2.46 & 0.83 \\
\hline $\mathrm{CO}_{2}$ & - & 0.36 & 0.24 & 2.83 & 6.15 & 6.41 & 0.74 \\
\hline $\mathrm{C}_{1}-\mathrm{C}_{4}$ & - & 0.03 & 0.16 & 0.12 & 0.21 & 0.21 & 0.20 \\
\hline Isobutylene & - & 3.32 & 5.55 & 4.22 & 6.05 & 15.87 & 11.72 \\
\hline Pentenes (amylenes) & - & 1.44 & 1.29 & 0.95 & 0.92 & 0.86 & 1.03 \\
\hline isoprene & - & 16.87 & 22.50 & 15.83 & 16.27 & 22.37 & 19.31 \\
\hline Formaldehyde & - & 12.53 & 33.79 & 18.81 & 28.87 & 25.91 & 38.30 \\
\hline Tert-butanol & 1.32 & 1.46 & 0.18 & 0.87 & 0.64 & 0.70 & 0.61 \\
\hline $\mathrm{i}-\mathrm{C}_{8}$ & 1.71 & 1.82 & 1.67 & 1.86 & 1.70 & 0.83 & 0.38 \\
\hline 3-methylbutan-2-1 & 4.19 & 3.87 & 5.47 & 3.49 & 3.95 & 3.069 & 2.42 \\
\hline 3-methylbuten-3-ol-1 & 3.47 & 3.01 & 1.46 & 3.41 & 1.88 & 0.50 & 0.26 \\
\hline 4-methylenetetra-hydropyran & 0.79 & 1.29 & 0.70 & 1.23 & 0.97 & 0.93 & 0.69 \\
\hline 4-methyl-3,6-dihydropyran & 29.39 & 13.88 & 2.64 & 10.14 & 3.63 & 0.49 & 0.37 \\
\hline 4,4-dimethyl-1,3-dioxane & 7.33 & 7.05 & 1.01 & 6.39 & 0.88 & 0.27 & 0.09 \\
\hline 3-methylbutanediol-1,3 & 0.14 & 0.10 & 0.25 & 0.12 & 0.06 & 0.04 & 0.14 \\
\hline 1-tert-butoxy-2-methylpropanol-2 & 0.38 & 0.15 & 0.18 & 0.25 & 0.09 & 0.08 & 0.08 \\
\hline 4-methyltetra-hydropyranol-4 & 0.01 & 0.09 & 0.30 & 0.07 & 0.07 & 0.24 & 0.64 \\
\hline (4,4-dimethyl-1,3-dioxanyl-5) methanol & 22.88 & 3.22 & 0.63 & 0.66 & 0.55 & 0.08 & 0.29 \\
\hline Decomposition degree of BP, $\%$ & & 14.54 & 26.12 & 28.53 & 34.08 & 11.82 & 28.25 \\
\hline Coke content in transmitted BPs, wt $\%$ & - & 0.89 & 0.42 & 0.54 & 0.86 & 0.39 & 1.31 \\
\hline
\end{tabular}

* The remaining, unidentified components; ** Bent and Kaol, respectively, catalysts based on natural bentonite and kaolin clays. 
phases in relation to 3-methylbutanone-2 is difficult to compare in our conditions [15].

Natural bentonite and kaolin clay catalysts are noticeably inferior to the Kaol-250 and Kaol-350 phases in terms of the yield of the conversion products of the organic BP mixture. It is worth noting that the selectivity of their action is directed more towards the formation of the most useful products of isobutylene, isoprene, and formaldehyde.

The amount of deposited coke on the studied synthetic and natural catalytic structures is significantly different. This can be influenced by the following factors: the specific surface area, the accessibility of small pores, the stability of the active centers of the surface and the catalytic surface as a whole under the influence of the reaction medium, and others [33]. The structural-morphological and acid-base features of each synthesized phase, apparently, make an additional quantitative contribution to the incidental processes of coke formation.

\section{CONCLUSIONS}

The results of studying the catalytic activity of the synthetic samples of aluminosilicates of different morphologies and chemical compositions revealed the contribution of individual phases to the course of certain routes in a cascade of reactions that are incidental in the process of isoprene synthesis. Catalysts with the structure of montmorillonite (Mt) and saponite (Sap) were found to play a significant role in reducing the gasification of organic raw materials and increasing the yield of isoprene; groups of kaolinite with the spherical initial morphology of the particles (Kaol250) were found to play a significant role in the increase in the yield of formaldehyde and in it, together with a sample of the kaolinite group with a platy morphology (Kaol-350), in the degree of decomposition of heteroatomic and heterocyclic compounds. None of the synthesized phases showed a pronounced advantage with respect to the reactions of isobutylene formation.

The information obtained on the contribution of individual phases of mineral catalysts to the conversion of organic BPs provides valuable information on possible ways of using them in the composition of composite catalysts, whose properties can be controlled depending on the composition of the utilized raw material.

\section{FUNDING}

This study was carried out as part of a state assignment of the Institute of Silicate Chemistry, Russian Academy of Sciences, with the support of the Ministry of Education and Science of Russia (topic no. AAAA-A19-119022290092-5).

\section{CONFLICT OF INTEREST}

The authors declare that they have no conflict of interest.

\section{OPEN ACCESS}

This article is licensed under a Creative Commons Attribution 4.0 International License, which permits use, sharing, adaptation, distribution and reproduction in any medium or format, as long as you give appropriate credit to the original author(s) and the source, provide a link to the Creative Commons license, and indicate if changes were made. The images or other third party material in this article are included in the article's Creative Commons license, unless indicated otherwise in a credit line to the material. If material is not included in the article's Creative Commons license and your intended use is not permitted by statutory regulation or exceeds the permitted use, you will need to obtain permission directly from the copyright holder. To view a copy of this license, visit http://creativecommons.org/licenses/by/4.0/.

\section{REFERENCES}

1. Asghar, U., Masoom, A., Javed, A., and Abbas, A., Economic analysis of isoprene production from good year scientific process, Am. J. Chem. Eng., 2020, vol. 8, no. 3, pp. 63-69.

2. Senyek, M.L., Isoprene polymers, in Encyclopedia of Polymer Science and Technology, Hoboken: Wiley, 2008, p. 80.

3. Kellner, D., Weger, M., Gini, A., and Mancheño, O.G., $\mathrm{Pd}(\mathrm{OAc})_{2} / \mathrm{Ph}_{3} \mathrm{P}$-catalyzed dimerization of isoprene and synthesis of monoterpenic heterocycles, Beilstein J. Org. Chem., 2017, vol. 13, p. 1807.

4. Zhuravleva, K.A., Nazarov, A.A., Ponikarov, S., and Zhuravleva, K.A., Synthesis of isoprene from isobutylene and formaldehyde, Vestn. Kazan. Tekhnol. Univ., 2012, no. 23, pp. 36-38.

5. Sushkevich, V.L., Ordomsky, V.V., and Ivanova, I.I., Skeletal isomerization of 1-butene over micro/mesoporous materials based on fer zeolite, Appl. Catal., A, 2012, p. 441.

6. Weitz, H.M. and Loser, E., Isoprene, in Ullmann's Encyclopedia of Industrial Chemistry, Weinheim: WileyVCH, 2002, pp. 264-322.

7. Dykman, A.S., Poluchenie izoprenovogo kauchuka (Isoprene Rubber Production), St. Petersburg: GIODR, 2020.

8. Odyakov, V.F. and Matveev, K.I., Catalytic methods for producing citral from products of basic organic synthesis, Khim. Inter. Ustoich. Razvit., 2001, vol. 9, no. 4, pp. 503-517.

9. Garaeva, G.T., Anisimova, V.I, and Suvorova, I.A., Synthesis of isoprene from isobutylene and formaldehyde, Vestn. Kazan. Tekhnol. Univ., 2015, no. 8, pp. 117-118.

10. Batalin, O.E., Dykman, A.S., Gerasimova, M.A., Lyulyak, N.V., Pokrovskaya, L.V., Golovachev, A.M., Sofronov, V.P., Osovskii, E.L., Starshinov, B.N., Krasnov, V.A., Gagin, A.V., Prudnikov, A.K., and Rubin- 
shtein, E.I., Catalyst for the cleavage of high boiling isoprene synthesis by-products, USSR Patent SU1819400A3, 1996.

11. Dykman, A.S., Leont'ev, P.Yu., and De Vekki, A.V., Thermal hydrolysis of by-products of site of 4,4-dimethyl-1,3-dioxane synthesis, Neftepererab. Neftekhim., 2013, no. 9, p. 35.

12. Mccabe, R.W. and Adams, J.M., Clay minerals as catalysts, in Handbook of Clay Science, Amsterdam: Elsevier, 2013, pp. 491-538.

13. Theng Benny, K.G., Clay Mineral Catalysis of Organic Reactions, Boca Raton, FL: CRC, 2019, p. 440.

14. Kirpichnikov, P.A, Beresnev, V.V., and Popova, L.M., Al'bom tekhnologicheskikh skhem osnovnykh proizvodstv promyshlennogo sinteticheskogo kauchuka, Ucheb. posobie dlya VUZov (Album of Technological Schemes of the Main Productions of Industrial Synthetic Rubber, The School-Book for Higher School), Leningrad: Khimiya, 1986.

15. Vershinin, K.A., Isoprene reactions under conditions of liquid-phase decomposition of 4,4-dimethyldioxane-1,3, Cand. Sci. (Chem.) Dissertation, St. Petersburg: All-Russ. Res. Inst. Petrochem. Process., Northwest. State Correspond. Tech. Univ., 2011.

16. Pinson, V.V., Dykman, A.S., Leont'ev, P.Yu., and De Vekki, A.V., Identification of by-products in the manufacture of 4,4-dimethyl-1,3-dioxane, Izv. SPbGTI(TU), 2015, no. 28 , p. 51.

17. Nagendrappa, G., Organic synthesis using clay and clay-supported catalysts, Appl. Clay Sci., 2011, vol. 53, no. 2, p. 106.

18. Belbachir, M. and Bensaoula, A., Composition and method for catalysis using bentonites, US Patent, no. 7094823, 2006.

19. Dumitriu, E., On, D.T., Kaliaguine, S., Isoprene by prins condensation over acidic molecular sieves, $J$. Catal., 1997, vol. 170, p. 150.

20. Adams, J.M. and Clapp, T.V., Reactions of the conjugated dienes butadiene and isoprene alone and with methanol over ion-exchanged montmorillonites, Clays Clay Miner., 1986, vol. 34, p. 287.

21. Bergaya, F. and Lagaly, G., Clay minerals as catalysts, in Developments in Clay Science, Amsterdam: Elsevier, 2013, vol. 5, Chap. 4.3, pp. 491-538.
22. Golubeva, O.Yu., Ul’yanova, N.Yu., Kostyreva, T.G., Drozdova, I.A., and Mokeev, M.V., Synthetic nanoclays with the structure of montmorillonite: preparation, structure, and physico-chemical properties, Glass Phys. Chem., 2013, vol. 39, no. 5, pp. 533-539.

23. Golubeva, O.Yu., Effect of synthesis conditions on hydrothermal crystallization, textural characteristics and morphology of aluminum-magnesium montmorillonite, Microporous Mesoporous Mater., 2016, vol. 224, p. 271.

24. Zakharova, N.V., Sychev, M.M., Korsakov, V.G., and Myakin, S.V., Evolution of donor-acceptor centers on the surface of $\mathrm{BaTiO}_{3}-\mathrm{CaSNO}_{3}$ ferroelectric materials in the course of their dispersion, Kondens. Sredy Mezhfaz. Granitsy, 2011, vol. 13, no. 1, p. 56.

25. Ralph, E., Differential thermal analysis of clay minerals and other hydrous materials, Am. Mineralog., 1942, vol. 27, no. 11, p. 746.

26. Peng, Y., Nanosized Tubular Clay Minerals: Halloysite and Imogolite, Amsterdam: Elsevier, 2016, p. 754.

27. Evtushenko, E.I., Comprehensive analysis of structural changes in hydrothermally stabilized kaolins, Vestn. BGTU im. V. G. Shukhova, 2012, no. 3, p. 150.

28. Vakalova, T.V., Khabas, T.A., Vereshchagin, V.I., and Mel'nik, E.D., Gliny. Osobennosti struktury $i$ metody issledovaniya (Clays. Features of the Structure and Research Methods), Tomsk: TGS, 1998.

29. Sing, K.S.W., Everett, D.H., Haul, R.A.W., Moscou, L., Pierotti, R.A., Rouquerol, J., and Siemieniewska, T., Reporting physisorption data for gas/solid systems with special reference to the determination of surface area and porosity, Pure Appl. Chem., 1985, vol. 57, no. 4, p. 603 .

30. Michot, L.J. and Villieras, F., Assessment of surface energetic heterogeneity of synthetic Na-saponites. The role of layer charge, Clay Miner., 2002, vol. 37, p. 39.

31. Neaman, A., Pelletier, M., and Villieras, F., Effects of thermal treatment, exchangeable cation and compression on textural properties of MX-80 bentonite, Appl. Clay Sci., 2003, vol. 22, p. 153.

32. Carrado, K., Csenscits, R., Thiyagarajan, P., Seifert, S., and Macha, S.M., Harwood, J.S., Crystallization and textural porosity of synthetic clay minerals, J. Mater. Chem., 2002, vol. 12, p. 3228.

33. Buyanov, R.A., Zakoksovyvanie katalizatorov (Coking of Catalysts), Novosibirsk: Nauka, 1983. 